\title{
老人性骨粗鬆症に対する性ホルモン・甲状腺ホルモン合剤と 結合型エストロゲン製剤の効果
}

\section{一活性型ビタミン $\mathrm{D}_{3}$ 製剤との比較一}

東京都老人医療センター研究検査科

$$
\text { 白木正孝 }
$$

東京大学医学部老年病学教室

$$
\text { 折茂肇 }
$$

\section{The Effect of Estrogen and, Sex - Steroids and Thyroid Hormone Preparation on Bone Mineral Density in Senile Osteoporosis . \\ - A comparative study of the effect of $1 \alpha-$ hydroxycholecalciferol $\left(1 \alpha-\mathrm{OHD}_{3}\right)$ on senile osteoporosis -}

\section{Masataka SHIRAKI ${ }^{1)}$ and Hajime ORIMO ${ }^{2)}$}

1) Department of Laboratory Medicine, Tokyo Metropolitan Geriatric Hospital, 35-2, Sakaecho, Itabashiku, Tokyo

2) Department of Geriatrics, Faculty of Medicine, Tokyo University, 7-3-1, Hongo, Bunkyoku, Tokyo

Key Words; senile osteoporosis, conjugated estrogen, sex - steroidsthyroid hormone preparation, active vitamin $\mathrm{D}_{3}$, bone mineral density

In order to assess the effect of sex steroids on bone mineral density in Japanese with senile osteoporosis, the bone mineral density in $1 / 3$ distal site of radius was measured serially before and after treatment for 2 years using single photon absorptiometry.

Sixty seven old females with senile osteoporosis were divided into 4 groups, Group 1 $(\mathrm{n}=28$, mean age; $74.4 \pm 1.3 \mathrm{y}$. o., mean $\pm \mathrm{SEM})$ was the control group, Group $2(\mathrm{n}=14$, mean age; $73.7 \pm 1.7 \mathrm{y} . \mathrm{o}$.$) was treated with 0.5-1.0 \mu \mathrm{g} /$ day of $1 \alpha-\mathrm{OHD}_{3}$, Group $3(\mathrm{n}=12$, mean age; $75.4 \pm 2.9 \mathrm{y} .0$.) was treated with conjugated estrogen (Premarin ${ }^{\circledR}$ ) in a dose of $0.3125 \mathrm{mg} /$ day $(3 \sim 4$ weeks administration followed by 1 week rest) and Group $4(\mathrm{n}=13$, mean age; $76.4 \pm 1.8 \mathrm{y} .0$. ) was treated with sex-steroids (pregnenolone : androstenedione : androstenediol $:$ testosterone $:$ estrone $=1.0 \mathrm{mg}: 1.0 \mathrm{mg}: 0.5 \mathrm{mg}: 0.1 \mathrm{mg}: 5 \mu \mathrm{g} /$ tablet $)$ and thyroid hormone (thyroid-sicca $7.5 \mathrm{mg} /$ tablet) preparation in a dose of 2 tablets/day .

When the radial bone mineral density (RMD) before the treatment was taken as $100 \%$, RMDs of each group at $6,12,18$ and 24 months were $96.4 \pm 3.1 \%, 97.3 \pm 2.0 \%, 93.7 \pm 2.1 \%$ and $96.1 \pm 1.8 \%$ in Group 1, $100.8 \pm 2.8 \%, 106.4 \pm 2.1 \%, 101.3 \pm 3.4 \%$ and $108.8 \pm 2.9 \%$ in Group 
2, $103.0 \pm 2.8 \%, 106.2 \pm 3.5 \%, 105.9 \pm 4.3 \%$ and $100.2 \pm 4.7 \%$ in Group 3, 105.3 $2.2 \%$, $104.7 \pm 2.3 \%, 112.6 \pm 6.4 \%$ and $112.1 \pm 6.7 \%$ in Group 4 , respectively.

Therefore, significant increases in RMD were observed in Groups 2, 3 (transient) and 4 when compared with Group 1.

In Group 3, serum level of parathyroid hormone (PTH) was significantly $(\mathrm{p}<0.05)$ increased from $0.28 \pm 0.03 \mathrm{ng} / \mathrm{m} \ell$ before the treatment to $0.55 \pm 0.15 \mathrm{ng} / \mathrm{m} \ell$ at 24 months after the treatment. In Group 2, transient ( 6 months after the treatment) but significant $(\mathrm{p}<0.01)$ increase in urinary $\mathrm{Ca} /$ Creatinine ratio from $0.15 \pm 0.04$ to $0.20 \pm 0.03$ was found. Serum $\mathrm{A} 1-\mathrm{P}$ activities in Group 4 was shown to increase transiently from $131 \pm 10$ IU to $151 \pm 12 \mathrm{IU}(\mathrm{p}<0.05)$ at 6 months and to $158 \pm 13 \mathrm{IU}(\mathrm{p}<0.01)$ at 12 months followed by subsequent decrease to $135 \pm 6 \mathrm{IU}$ at 18 months and $133 \pm 10 \mathrm{IU}$ at 24 months after the treatment. Serum level of calcium in Group 4 was decreased from $9.6 \pm 0.1 \mathrm{mg} / \mathrm{dl}$ to $9.1 \pm 0.2 \mathrm{mg} / \mathrm{dl}$ at 18 months after the treatment $(\mathrm{p}<0.05)$. These findings indicated the following possibilities. 1) Administration of $1 \alpha-\mathrm{OHD}_{3}$ and, sex hormones and thyroid hormone preparation are effective in increasing bone mineral density in senile osteoporosis. 2) Administration of a low dose of estrogen might increase bone mineral density in senile osteoporosis. However, this increment in bone mineral density is transient possibly because of the subsequent rise in serum level of PTH. 3) The mechanisms of these drugs in bone metabolism might be different.

\section{緒言}

骨粗鬆症は骨量の低下を主徵とする症候群である。本症は老年者女性に多発し, 骨脆弱性を来す ため骨折を生じ，老年者の日常生活を損なら。従って，本症の予防治療法の開発は急務であると考 えられている。本症を予防するのか, 治療すべきなのかについては議論のあるところであるが, 既

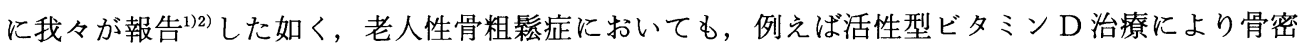
度が増加すると文，新たな骨折の発生が有意に抑制される2)ことが知られている。従って，骨量が既 に減少した老人性骨粗鬆症における治療が全く無意味であるとは思えない。

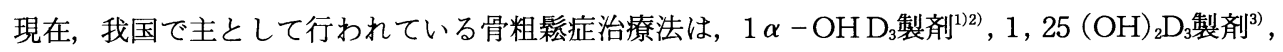
及びカルチトニン製剤(4)の投与である。それに対し欧米諸国においては，エストロゲン治療が主流 を占めている ${ }^{5) ~}$ 。しかしアジア人種では白人種に比し血中エストロゲン值が低值を示す ${ }^{8)}$ との報告 や老人性骨粗鬆症の一部にエストロゲンの前駆体であるアンドロゲン分泌が低下している群が存在 している ${ }^{9) 11)} と の$ 報告などから，日本人においても，エストロゲン製剤の老人性骨粗鬆症に対する 効果を検証してみる必要があると考学られる。

最近, 大西ら ${ }^{12}$ は, 性ホルモン・甲状腺ホルモン合剤が, 骨粗鬆症の骨密度を改善し得たと報告 した。そこで今回の検討においては，老人性骨粗鬆症例に対し、本邦での標準的治療薬である $1 \alpha$ $\mathrm{OH} \mathrm{D}_{3}$ ，主として諸外国における標準的治療薬である結合型エストロゲン製剤，及び性ホルモン・ 甲状腺ホルモン合剂の 3 種を投与し, 対照群の骨密度又は生化学所見の推移と比較検討した。 


\section{対象と方法}

\section{1) 対象}

対象は東京都老人医療センターへ通院中の 56 ～88才の老年女性67例である。これらの症例は，レ 線学的検討により春椎圧迫骨折を有するか，または橈骨骨密度が $0.5 \mathrm{~g} / \mathrm{cm}^{2}$ 以下のいずれかの基準 で骨粗鬆症を有すると判断された。この上記 67 例は, 無処置群 $(\mathrm{C}$ 群 : $\mathrm{n}=28), 1 \alpha-\mathrm{OH} \mathrm{D}_{3}$, 投与 群 $(1 \alpha$ 群 $: \mathrm{n}=14)$, 結合型エストロゲン投与群 $(\mathrm{E}$ 群 $: \mathrm{n}=12)$ 及び性ホルモン・甲状腺ホルモン 投与群 (MHF 群 : $\mathrm{n}=13)$ に分割された。

ここで $\mathrm{C}$ 群， $1 \alpha$ 群， $\mathrm{E}$ 群， MHF 群はいずれも観察期間の $80 \%$ 以上が，これらの処置をほどこ された症例と規定した。

\section{2）薬威投与方法}

$1 \alpha$ 群において, $1 \alpha-\mathrm{OH} \mathrm{D}_{3}$ の投与量は $0.5 \sim 1.0 \mu \mathrm{g} /$ 日の間での可変用量とした。即ち $1 \alpha-\mathrm{OH}$ $\mathrm{D}_{3} 1.0 \mu \mathrm{g} /$ 日より投与を開始し, 血清 $\mathrm{Ca}$ 值 $10.5 \mathrm{mg} / \mathrm{dl}$ 以上又は尿中 $\mathrm{Ca} / \mathrm{Cr}$ 比 0.3 以上を呈したら 減量することとした。

結合型エストロゲン製剂としてはプレマリン $0.3125 \mathrm{mg} /$ 日を3乃至 4 週間投薬し，1週間休薬する 方法を採った。ここでプロゲステロン製剤は用いなかった。

甲状腺ホルモン・性ホルモン合剤としてはメサルモン $\mathrm{F}^{\circledR}$ 錠 2 錠/日が継続投与された。この処置 による各ホルモンの一日投与量は下記の如くである。

プレグネノロン $2.0 \mathrm{mg}$, アンドロステンジオン $2.0 \mathrm{mg}$, アンドロステンジオール $1.0 \mathrm{mg}$, テスト ステロン $0.2 \mathrm{mg}$ ，エストロン $10 \mu \mathrm{g}$ 及び乾燥甲状腺末 $15.0 \mathrm{mg}$

\section{3）観察項目とその測定法}

対象例は全例左橈骨遠位端1/3部分において橈骨骨密度 (radial mineral density : RMD, g/ $\mathrm{cm}^{2}$ ) が測定された。即ち既報13) の如く，Norland 社製 Bone Mineral analyzer Type 278 (Norland Co. WI, USA）を用いた single photon absorptiometryにより測定した。

本法の long-term reproducibility は，3\%と考えられた ${ }^{14)}$ 。

血清カルシウム $(\mathrm{Ca})$, リン $(\mathrm{P})$, アルカリフォスファターゼ活性 $(\mathrm{A} 1-\mathrm{P})$, 尿素窒素 $(\mathrm{BUN})$, クレアチニン $(\mathrm{Cr})$ ，尿カルシウム／クレアチニン $(\mathrm{Ca} / \mathrm{Cr})$ 比及びリン/クレアチニン $(\mathrm{P} / \mathrm{Cr})$ 比 が経時的に測定された。これらの測定は Automated colorimetric assay (Toshiba 80-S, Toshiba ME Co, Tokyo）によりなされた。尿 $\mathrm{Ca} / \mathrm{Cr}$ 及び $\mathrm{P} / \mathrm{Cr}$ 比は原則として早朝空腹尿を用いて測定し た。

血清副甲状腺ホルモン（PTH）值はヤマサ醬油社製 HS-PTH, RIA 系にて測定した（Yamasa shyoyu Co.Chiba)。本法の最低 assay 感度は $0.08 \mathrm{ng} / \mathrm{ml}$ であり, 当センターにおける再現性は 19.8\%であった。

これら全ての測定は $1 \sim 2$ ケに1度行い，6ヶ月間に行われた $3 \sim 6$ 回の測定值の平均值をもって当 該患者の測定值とみなした。

\section{4) 推計学的方法}

結果は全て平均士標準誤差にて表記した。各群間比較は Student’s t-test を用い, 群内比較は Paired $\mathrm{t}$ - test を用いた。 
結 果

\section{1）患者背景と検討継続性について}

各群の患者背景因子につき表1に示した。表1に示す如く，各群はおおむね抣一な集団と考兄られ たが，MHF 群のみが C 群に比し，血清 $\mathrm{Ca}$ 值及び尿 $\mathrm{Ca} / \mathrm{Cr}$ 比が有意に高值であった。 $\mathrm{MHF}$ 群中 血清 $\mathrm{Ca}$ 值が $10.5 \mathrm{mg} / \mathrm{dl}$ をこえる高 $\mathrm{Ca}$ 血症を呈する例は一例もなく，いずれも正常範囲内であっ た。しかし尿 $\mathrm{Ca} / \mathrm{Cr}$ 比 0.3 越える高 $\mathrm{Ca}$ 㽷症を示した例は，他群では一例も存在しなかったが， $\mathrm{MHF}$ 群では13例中4例 $(30.8 \%)$ とみられた。

老年者の長期観察試験においては，検討継続性が問題となる。C 群及び $1 \alpha$ 群は全例 2 年間の経過 観察が可能であった。しかし E 群においては2例が通院不可能（家族の事情により）となり，18ヶ 月で脱落した。また 3 例は原因不明のまま通院が中断され，結局 2 年間を完全に終了した例は，12例 中7例 (58.3\%) であった。

MHF 群では 2 例が 12 ヶ月付近でそれぞれ肺炎及び交通事故で死亡された。また糖尿病，慢性呼 吸不全の悪化のため入院により12ヶ月で中断されたもの2例, 原因不明の中断例が 4 例存在し，2年 間を終了した例は13例中5例 (38.5\%) であった。従って以下の検討は各観察期間で上記の如くの症 例数の変動が存在する。

Table 1 Back-ground data of subjects

\begin{tabular}{|c|c|c|c|c|}
\hline & control & $\begin{array}{c}1 \alpha-0 \mathrm{HD}_{3} \\
(0.5 \sim 1.0 \mu \mathrm{g} / \mathrm{day})\end{array}$ & $\begin{array}{c}\text { Premarin } \\
(0.3125 \mathrm{mg} / \text { day })\end{array}$ & $\begin{array}{c}\text { MHF } \\
(2 T / \text { day })\end{array}$ \\
\hline $\begin{array}{l}\text { Number of } \\
\text { subjects }\end{array}$ & 28 & 14 & 12 & 13 \\
\hline Age $(y .0)$. & $74.4 \pm 1.3$ & $73.7 \pm 1.7$ & $75.4 \pm 2.9$ & $76.4 \pm 1.8$ \\
\hline RMD $\quad\left(\mathrm{g} / \mathrm{cm}^{2}\right)$ & $0.46 \pm 0.02$ & $0.45 \pm 0.02$ & $0.40 \pm 0.02$ & $0.40 \pm 0.02$ \\
\hline $\mathrm{s}-\mathrm{Ca}(\mathrm{mg} / \mathrm{d} l)$ & $9.1 \pm 0.1$ & $9.2 \pm 0.1$ & $9.3 \pm 0.1$ & $9.6 \pm 0.1 \neq *$ \\
\hline $\mathrm{s}-\mathrm{P} \quad(\mathrm{mg} / \mathrm{dl})$ & $3.6 \pm 0.1$ & $3.3 \pm 0.1$ & $3.4 \pm 0.1$ & $3.5 \pm 0.1$ \\
\hline$A I-P \quad(I U)$ & $145 \pm 8$ & $149 \pm 14$ & $131 \pm 11$ & $131 \pm 10$ \\
\hline BUN $(\mathrm{mg} / \mathrm{d} \ell)$ & $17.3 \pm 1.0$ & $18.3 \pm 1.1$ & $18.9 \pm 1.2$ & $19.6 \pm 1.1+$ \\
\hline $\operatorname{Cr} \quad(\mathrm{mg} / d \ell)$ & $0.86 \pm 0.03$ & $0.84 \pm 0.04$ & $0.98 \pm 0.08$ & $0.90 \pm 0.06$ \\
\hline PTH $\quad(n g / m \ell)$ & $0.42 \pm 0.05$ & $0.36 \pm 0.07$ & $0.29 \pm 0.03$ & $0.41 \pm 0.08$ \\
\hline $\mathrm{u}-\mathrm{Ca} / \mathrm{Cr}$ & $0.11 \pm 0.02$ & $0.15 \pm 0.04$ & $0.14 \pm 0.02$ & $0.20 \pm 0.04$ \\
\hline $\mathrm{u}-\mathrm{P} / \mathrm{Cr}$ & $0.52 \pm 0.07$ & $0.47 \pm 0.05$ & $0.52 \pm 0.06$ & $0.63 \pm 0.07$ \\
\hline
\end{tabular}

The back-ground data of the subjects are listed in Table 1. Serum level of calcium and urinariy $\mathrm{Ca} / \mathrm{Cr}$ ratio in Group 4 are significantly higher $(p<0.01$ and $p<0.05)$ than those in Group 1.

**, *; $p<0.01,0.05$ vs control

$+; p<0.05$ vs $1 \alpha-\mathrm{OHD}_{3}$

\section{2) 骨密度の変動について}

左橈骨 $1 / 3$ 遠位端骨密度 (RMD) を SPA 法にて追求した。C 群， $1 \alpha$ 群， E 群及び MHF 群の観

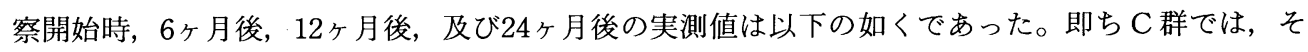

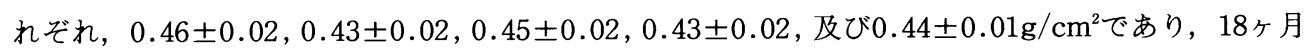
後及び 24 ケ後の值が前值に比し有意 $(\mathrm{p}<0.01$ 及び $\mathrm{p}<0.05 ;$ paired $\mathrm{t}-$ test $)$ に低值を示した。

\section{第67巻 第 2 号}


この群では 2 年後に約 $4 \%$ の骨密度の減少をみた。 $1 \alpha$ 群では同様に, $0.45 \pm 0.02,0.45 \pm 0.02,0.46$ $\pm 0.02,0.45 \pm 0.03$ 及び $0.48 \pm 0.02 \mathrm{~g} / \mathrm{cm}^{2}$ と変動し，12ヶ月後及び 24 月後は前值に比し有意 $(\mathrm{p}<$ 0.05) の増加を示した。 $\mathrm{E}$ 群では同様に $0.40 \pm 0.02,0.41 \pm 0.02,0.42 \pm 0.03,0.42 \pm 0.02$ 及び 0.43 $\pm 0.04 \mathrm{~g} / \mathrm{cm}^{2}$ を示した。結果的に $\mathrm{E}$ 群では群内では $\mathrm{RMD}$ は有意に増加しなかった。しかし C 群に 比して，12ヶ月及び18ヶ月後の変化率 $(106.2 \pm 3.5 \%$ 及び， $105.9 \pm 4.3 \%)$ は有意 $(\mathrm{p}<0.05$ 及び

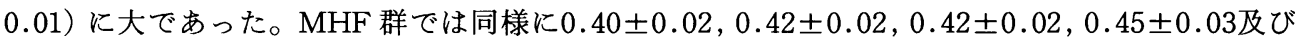
$0.44 \pm 0.02 \mathrm{~g} / \mathrm{cm}^{2}$ を示した。6r月後の值は前值に比し有意 $(\mathrm{p}<0.05)$ の上昇を示した。変化率で みれば，いずれの観察時点においてもC 群より変化率が大であった。これら薬剤投与群と C 群の $\mathrm{RMD}$ の変化率をまとめて図1に示した。

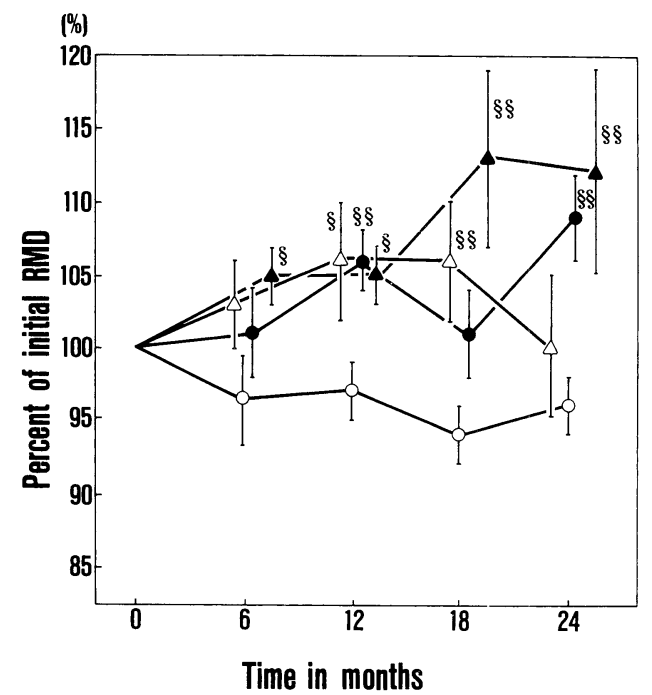

Fig. 1 Effect of drugs on radial mineral density (RMD) in senile osteoporosis

Time course changes in RMDs in various groups are illustrated here. When the initial $\mathrm{RMD}$ was taken as $100 \%$, the percent $\mathrm{RMD}$ in group 1 (control $\bigcirc-\mathrm{O}$ ) was decreased to $96.1 \pm 1.8 \%$ during the observation period. On the other hand, significant rise in the percent $\mathrm{RMD}$ in every groups treated

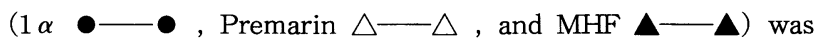
found.

$\S ; \mathrm{p}<0.05$ vs control, $\S \S ; \mathrm{p}<0.01$ vs control

\section{3）血液生化学所見の変動}

各群の血清 $\mathrm{Ca}, \mathrm{P}, \mathrm{BUN}$ 及び $\mathrm{Cr}$ の変動を実測值及び変化率で表 2,3 示した。C 群においては 経時的に $\mathrm{P}$ 值が上昇を示した。1 $\alpha$ 群においては $\mathrm{P}$ 值は変動を示さず， BUN 及び $\mathrm{Cr}$ が上昇を示 した。しかしこの BUN 及び Cr の変動域は正常範囲内であった。E群でも BUN の上昇がみられ たが，Cr值は逆に低下した。MHF 群では血清 $\mathrm{Ca}, \mathrm{P}, \mathrm{BUN}$ 及び Cr が全て低下を示した。しかし これらの変化は全て正常域内であり，その変動も経過上一貫した変動ではなかった。 
Table 2 Effect of drugs on serum level of calcium (Ca) and phosphorus (P)

\begin{tabular}{|c|c|c|c|c|c|c|c|c|}
\hline$C^{T x}$ & \multicolumn{2}{|c|}{ control } & \multicolumn{2}{|c|}{$1 \alpha-O H D_{3}$} & \multicolumn{2}{|c|}{ Premarin } & \multicolumn{2}{|c|}{ MFF } \\
\hline $\begin{array}{l}\text { duration ters } \\
\text { of } T x\end{array}$ & $\begin{array}{c}\mathrm{s}-\mathrm{Ca} \\
(\mathrm{mg} / d \ell)\end{array}$ & $\begin{array}{c}\mathrm{s}-\mathrm{P} \\
(\mathrm{mg} / \mathrm{dl})\end{array}$ & $\begin{array}{c}\mathrm{s}-\mathrm{Ca} \\
(\mathrm{mg} / \mathrm{dl})\end{array}$ & $\begin{array}{c}\mathrm{s}-\mathrm{P} \\
(\mathrm{mg} / \mathrm{d \ell})\end{array}$ & $\begin{array}{c}\mathrm{s}-\mathrm{Ca} \\
(\mathrm{mg} / d l)\end{array}$ & $\begin{array}{c}\mathrm{s}-\mathrm{P} \\
(\mathrm{mg} / d \ell)\end{array}$ & $\begin{array}{c}\mathrm{s}-\mathrm{Ca} \\
(\mathrm{mg} / d \ell)\end{array}$ & $\underset{(\mathrm{mg} / d \ell)}{\mathrm{s}-\mathrm{P}}$ \\
\hline 0 month & $\begin{array}{c}9.1 \pm 0.1 \\
(100)\end{array}$ & $\begin{array}{l}3.6 \pm 0.1 \\
\quad(100)\end{array}$ & $\begin{array}{c}9.2 \pm 0.1 \\
(100)\end{array}$ & $\begin{array}{c}3.3 \pm 0.1 \\
(100)\end{array}$ & $\begin{array}{c}9.3 \pm 0.2 \\
(100)\end{array}$ & $\begin{array}{c}3.4 \pm 0.1 \\
(100)\end{array}$ & $\begin{array}{c}9.6 \pm 0.1 \\
(100)\end{array}$ & $\begin{array}{c}3.5 \pm 0.1 \\
(100)\end{array}$ \\
\hline 6 months & $\begin{array}{c}9.1 \pm 0.1 \\
(100.4 \pm 0.9)\end{array}$ & $\begin{array}{c}3.6 \pm 0.1 \\
(102.8 \pm 2.3)\end{array}$ & $\begin{array}{c}9.3 \pm 0.1 \\
(100.4 \pm 1.3)\end{array}$ & $\begin{array}{c}3.4 \pm 0.1 \\
(101.8 \pm 1.5)\end{array}$ & $\begin{array}{c}9.1 \pm 0.2 \\
(98.4 \pm 1.3)\end{array}$ & $\begin{array}{c}3.4 \pm 0.1 \\
(98.6 \pm 2.4)\end{array}$ & $\begin{array}{c}9.5 \pm 0.1 \\
(99.6 \pm 0.8)\end{array}$ & $\begin{array}{c}3.5 \pm 0.1 \\
(100.4 \pm 3.4)\end{array}$ \\
\hline 12 months & $\begin{array}{c}9.2 \pm 0.1 \\
(100.7 \pm 1.0)\end{array}$ & $\begin{array}{c}3.7 \pm 0.1 \\
(104.1 \pm 2.3)\end{array}$ & $\begin{array}{c}9.2 \pm 0.1 \\
(100.1 \pm 1.3)\end{array}$ & $\begin{array}{c}3.3 \pm 0.1 \\
(100.8 \pm 2.4)\end{array}$ & $\begin{array}{c}9.2 \pm 0.1 \\
(99.0 \pm 1.0)\end{array}$ & $\begin{array}{c}3.4 \pm 0.1 \\
(99.7 \pm 2.5)\end{array}$ & $\begin{array}{c}9.5 \pm 0.1 \\
(100.0 \pm 0.6)\end{array}$ & $\begin{array}{c}3.6 \pm 0.1 \\
(99.8 \pm 3.7)\end{array}$ \\
\hline 18 months & $\begin{array}{c}9.2 \pm 0.1 \\
(101.2 \pm 0.8)\end{array}$ & $\begin{array}{c}3.7 \pm 0.1 * \\
(105.0 \pm 2.0)\end{array}$ & $\begin{array}{c}9.3 \pm 0.1 \\
(99.5 \pm 0.9)\end{array}$ & $\begin{array}{c}3.2 \pm 0.1 \\
(96.3 \pm 3.7)^{5}\end{array}$ & $\begin{array}{c}9.3 \pm 0.2 \\
(100.3 \pm 1.5)\end{array}$ & $\begin{array}{c}3.4 \pm 0.1 \\
(100.8 \pm 4.1)\end{array}$ & $\begin{array}{r}9.1 \pm 0.2 * \\
(96.5 \pm 1.5)^{5}\end{array}$ & $\begin{array}{c}3.5 \pm 0.2 \\
(91.1 \pm 2.8)^{5 \S}\end{array}$ \\
\hline 24 months & $\begin{array}{c}9.2 \pm 0.1 \\
(101.7 \pm 1.0)\end{array}$ & $\begin{array}{c}3.7 \pm 0.1 \\
(103.6 \pm 2.5)\end{array}$ & $\begin{array}{c}9.3 \pm 0.1 \\
(100.3 \pm 1.1)\end{array}$ & $\begin{array}{c}3.3 \pm 0.1 \\
(99.1 \pm 3.7)\end{array}$ & $\begin{array}{c}9.3 \pm 0.3 \\
(100.0 \pm 1.2)\end{array}$ & $\begin{array}{c}3.4 \pm 0.2 \\
(100.2 \pm 5.6)\end{array}$ & $\begin{array}{c}9.2 \pm 0.1 \\
(97.3 \pm 1.1)\end{array}$ & $\begin{array}{c}3.5 \pm 0.2 \\
(93.0 \pm 4.0)\end{array}$ \\
\hline
\end{tabular}

Time course changes in serum level of calcium and phosphorus are listed in Table 2.

The percent change of those parameters when the initial values are taken as $100 \%$, are also listed. Inter- and intra-group comparisons of these parameters were made by non-paired and paired Student's t-test (two-tailed), respectively.

* ; $p<0.05$ vs 0 month

$\S ; p<0.05$ vs control, $\S \S ; p<0.01$ vs control

Table 3 Effect of drugs on renal function

\begin{tabular}{|c|c|c|c|c|c|c|c|c|}
\hline$T^{T x}$ & \multicolumn{2}{|c|}{ control } & \multicolumn{2}{|c|}{$1 \alpha-O H D_{3}$} & \multicolumn{2}{|c|}{ Premarin } & \multicolumn{2}{|c|}{ MFF } \\
\hline $\begin{array}{c}\text { duration ters } \\
\text { of } T x\end{array}$ & $\begin{array}{c}\text { BUN } \\
(\mathrm{mg} / d \ell)\end{array}$ & $\begin{array}{c}\mathrm{Cr} \\
(\mathrm{mg} / \mathrm{dl})\end{array}$ & $\begin{array}{c}\text { BUN } \\
(\mathrm{mg} / d \ell)\end{array}$ & $\begin{array}{c}\mathrm{Cr} \\
(\mathrm{mg} / \mathrm{d \ell})\end{array}$ & $\begin{array}{c}\text { BUN } \\
(\mathrm{mg} / d \ell)\end{array}$ & $\begin{array}{c}\mathrm{Cr} \\
(\mathrm{mg} / d \ell)\end{array}$ & $\begin{array}{c}\text { BUN } \\
(\mathrm{mg} / d \ell)\end{array}$ & $\underset{(\mathrm{mg} / \mathrm{dl})}{\mathrm{Cr}}$ \\
\hline 0 month & $\begin{array}{l}\text { 17. } 3 \pm 1.0 \\
(100)\end{array}$ & $\begin{array}{c}0.86 \pm 0.03 \\
(100)\end{array}$ & $\begin{array}{c}\text { 18. } 3 \pm 1.1 \\
(100)\end{array}$ & $\begin{array}{c}0.84 \pm 0.04 \\
\quad(100)\end{array}$ & $\begin{array}{c}\text { 18. } 9 \pm 1.2 \\
(100)\end{array}$ & $\begin{array}{c}0.98 \pm 0.08 \\
(100)\end{array}$ & $\begin{array}{c}19.6 \pm 1.1 \\
(100)\end{array}$ & $\begin{array}{c}0.90 \pm 0.06 \\
(100)\end{array}$ \\
\hline 6 months & $\begin{array}{c}17.7 \pm 0.7 \\
(105.5 \pm 3.5)\end{array}$ & $\begin{array}{r}0.85 \pm 0.03 \\
(100.4 \pm 2.3)\end{array}$ & $\begin{array}{c}20.6 \pm 1.8 \\
(111.4 \pm 5.6)\end{array}$ & $\begin{array}{c}0.95 \pm 0.07 * \\
(113.1 \pm 5.3)\end{array}$ & $\begin{array}{c}19.7 \pm 1.3 \\
(103.4 \pm 3.7)\end{array}$ & $\begin{array}{r}0.97 \pm 0.09 \\
(100.8 \pm 2.7)\end{array}$ & $\begin{array}{c}19.4 \pm 1.3 \\
(99.8 \pm 3.2)\end{array}$ & $\begin{array}{r}0.92 \pm 0.10 \\
(101.2 \pm 4.0)\end{array}$ \\
\hline 12 months & $\begin{array}{c}17.9 \pm 0.7 \\
(107.6 \pm 4.1)\end{array}$ & $\begin{array}{r}0.83 \pm 0.03 \\
(98.7 \pm 2.3)\end{array}$ & $\begin{array}{c}19.5 \pm 1.5 \\
(108.2 \pm 4.2)\end{array}$ & $\begin{array}{r}0.91 \pm 0.05 \\
(108.4 \pm 5.0)\end{array}$ & $\begin{array}{c}20.3 \pm 1.3 \\
(108.2 \pm 4.4)\end{array}$ & $\begin{array}{r}0.90 \pm 0.05 \\
(97.2 \pm 5.4)\end{array}$ & $\begin{array}{c}18.6 \pm 1.1 \\
(96.3 \pm 5.0)\end{array}$ & $\begin{array}{r}0.88 \pm 0.06 \\
(97.9 \pm 4.6)\end{array}$ \\
\hline 18 months & $\begin{array}{c}18.1 \pm 0.9 \\
(107.8 \pm 4.2)\end{array}$ & $\begin{array}{l}0.85 \pm 0.03 \\
(99.2 \pm 2.5)\end{array}$ & $\begin{array}{c}19.2 \pm 1.6 \\
(105.5 \pm 4.2)\end{array}$ & $\begin{array}{r}0.94 \pm 0.05 \\
(111.3 \pm 4.9)^{5}\end{array}$ & $\begin{array}{c}20.9 \pm 1.6 * \\
(116.7 \pm 4.9)\end{array}$ & $\begin{array}{l}0.90 \pm 0.06 \\
(93.6 \pm 6.4)+\end{array}$ & $\begin{array}{l}16.7 \pm 1.1 \\
(89.2 \pm 6.7)\end{array}$ & $\begin{array}{l}0.83 \pm 0.06 \\
(94.4 \pm 4.8)+\end{array}$ \\
\hline 24 months & $\begin{array}{c}18.2 \pm 1.0 \\
(107.7 \pm 4.0)\end{array}$ & $\begin{array}{r}0.85 \pm 0.04 \\
(99.9 \pm 2.8)\end{array}$ & $\begin{array}{c}19.3 \pm 1.3 \\
(105.6 \pm 3.5)\end{array}$ & $\begin{array}{r}0.92 \pm 0.06 \\
(110.7 \pm 4.6)\end{array}$ & $\begin{array}{c}19.0 \pm 1.3 \\
(105.0 \pm 2.6)\end{array}$ & $\begin{array}{r}0.88 \pm 0.07 \\
(90.3 \pm 6.3)\end{array}$ & $\begin{array}{l}17.4 \pm 1.3 \\
(96.8 \pm 8.1)+\end{array}$ & $\begin{array}{c}0.86 \pm 0.06 \\
(92.8 \pm 2.2)+\end{array}$ \\
\hline
\end{tabular}

Time course changes in serum level of BUN and creatinine $(\mathrm{Cr})$ are listed in Table 3.

The percent change of these parameters when the initial values are taken as $100 \%$, are also listed. Inter- and intra-group comparisons of these parameters were made by non-paired and paired Student's t-test (two-tailed), respectively.

*; $p<0.05$ vs 0 month, $+; p<0.05$ vs $1 \alpha-0 H D_{3}$, \#; $p<0.01$ vs Premal in

$\S ; p<0.05$ vs control, 
図2には血清 $\mathrm{A} 1-\mathrm{P}$ 活性の変化率を示した。C 群では $10 \%$ の変動内でやや増加したのに対し $1 \alpha$ 群及び $\mathrm{E}$ 群の $\mathrm{A} 1-\mathrm{P}$ 值は-10\%程度減少傾向を示した。C, $1 \alpha, \mathrm{E}$ 群間の $\mathrm{A} 1-\mathrm{P}$ の変動に差はみ られなかった。一方 MHF 群では投与開始後6及び $12 ヶ$ 月にて約 $20 \%$ 程度の活性上昇を認めた。し かし MHF 群の A1-P に対する効果は一時的で，18ヶ月後以降減少していった。

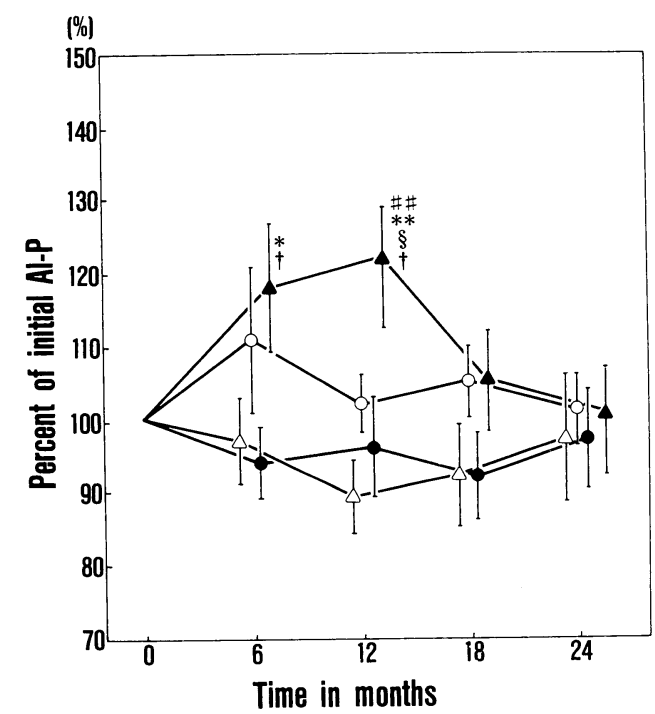

Fig. 2 Effect of drugs on Al-P activity in senile osteoporosis

Time course changes in serum $\mathrm{Al}-\mathrm{P}$ activities in various groups are illustrated here. When the initial $\mathrm{Al}-\mathrm{P}$ was taken as $100 \%$,

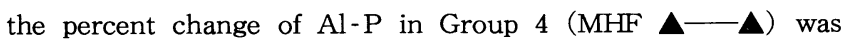
increased transiently at 6 months $\mathrm{p}<0.05$ vs 0 month and $1 \alpha$ ) and at 12 months $(\mathrm{p}<0.01$ vs 0 month and Premarin, $\mathrm{p}<0.05$ vs control and $1 \alpha$ ) after the treatment. The percent change of $\mathrm{Al}-\mathrm{P}$ in Group 4 was subsequently decreased to $100 \%$, eventhough the administration of the drug was continued.

$$
\begin{aligned}
& * ; \mathrm{p}<0.05 \text { vs } 0 \text { month, } * * ; \mathrm{p}<0.01 \text { vs } 0 \text { month } \\
& \S ; \mathrm{p}<0.05 \text { vs control, \#\#; }<<0.01 \text { vs Premarin } \\
& +; \mathrm{p}<0.05 \text { vs } 1 \alpha
\end{aligned}
$$

図3には，血清 PTH 值の変化率を示した。C, $1 \alpha$ 及び MHF 群が著明な変動を示さないのに比 し， E 群では観察期間中 PTH 值は上昇をつづけ，投与前値 $0.28 \pm 0.03 \mathrm{ng} / \mathrm{ml}$ より 24 ヶ月後には $0.55 \pm 0.15 \mathrm{ng} / \mathrm{ml}$ へと $(241.7 \pm 66.8 \%)$ 約 2.5 倍の上昇をみた。

\section{4）尿生化学所見の変動}

尿 $\mathrm{Ca} / \mathrm{Cr}$ 比及び $\mathrm{P} / \mathrm{Cr}$ 比の変動につき実測值及び前値を $100 \%$ とした際の各観察時点での変化率 を表4に示した。1 $\alpha$ 群では一過性（6ヶ月）にC 群に比し有意 $(\mathrm{p}<0.01)$ の尿 $\mathrm{Ca} / \mathrm{Cr}$ 比の高值を みた。一方 $\mathrm{MHF}$ 群の投与前值の $\mathrm{Ca} / \mathrm{Cr}$ 比の $\mathrm{C}$ 群に対する高值は6ヶ月後まで継続し, 以後は差を 認めなかった。 $\mathrm{E}$ 群では $\mathrm{Ca} / \mathrm{Cr}$ 比は低下する傾向を一過性に認めた（6ヶ月及び12ヶ月後）。 


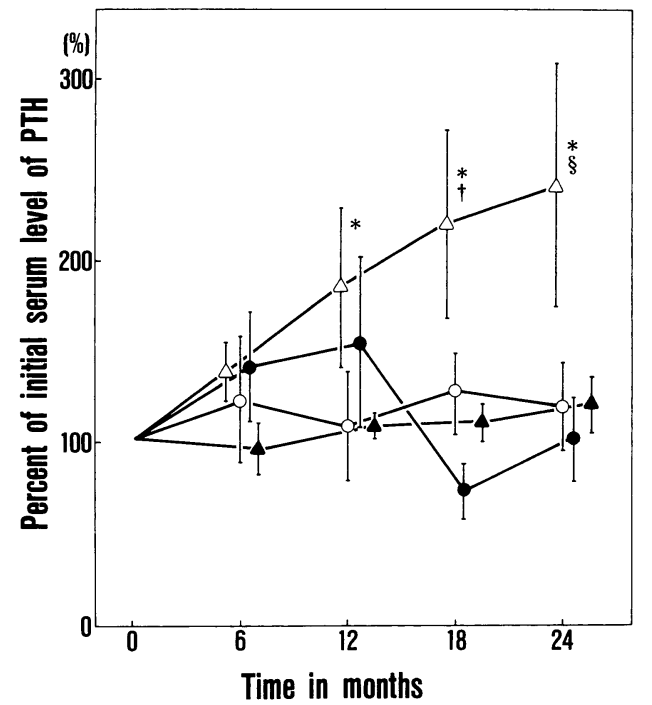

Fig. 3 Effect of drugs on the serum level of PTH in senile osteoporosis

Time course changes in serum level of PTH in various groups are shown. When the initial serum level of PTH was taken $100 \%$, significant increase in serum level of PTH in Group 3 was found.

$* ; \mathrm{p}<0.05$ vs 0 month,$\quad+; \mathrm{p}<0.05$ vs $1 \alpha$

$\S ; \mathrm{p}<0.05$ vs control

Table 4 Effect of drugs on urinary $\mathrm{Ca} / \mathrm{Cr}$ ratio and $\mathrm{P} / \mathrm{Cr}$ ratio

\begin{tabular}{|c|c|c|c|c|c|c|c|c|}
\hline $\mathrm{Tx}$ & \multicolumn{2}{|c|}{ control } & \multicolumn{2}{|c|}{$1 \alpha-O H D_{3}$} & \multicolumn{2}{|c|}{ Premarin } & \multicolumn{2}{|c|}{ MHF } \\
\hline $\begin{array}{l}\text { duration ters } \\
\text { of } T x\end{array}$ & $\mathrm{u}-\mathrm{Ca} / \mathrm{Cr}_{\mathrm{r}}$ & $\mathrm{u}-\mathrm{P} / \mathrm{Cr}$ & $\mathrm{u}-\mathrm{Ca} / \mathrm{Cr}$ & $\mathrm{u}-\mathrm{P} / \mathrm{Cr}$ & $\mathrm{u}-\mathrm{Ca} / \mathrm{Cr}$ & $\mathrm{u}-\mathrm{P} / \mathrm{Cr}$ & $\mathrm{u}-\mathrm{Ca} / \mathrm{Cr}$ & $\mathrm{u}-\mathrm{P} / \mathrm{Cr}$ \\
\hline 0 month & $\begin{array}{c}0.11 \pm 0.02 \\
(100)\end{array}$ & $\begin{array}{c}0.52 \pm 0.05 \\
\quad(100)\end{array}$ & $\begin{array}{c}0.15 \pm 0.04 \\
(100)\end{array}$ & $\begin{array}{c}0.43 \pm 0.03 \\
(100)\end{array}$ & $\begin{array}{c}0.14 \pm 0.02 \\
(100)\end{array}$ & $\begin{array}{c}0.52 \pm 0.06 \\
(100)\end{array}$ & $\begin{array}{c}0.10 \pm 0.24 \\
(100)\end{array}$ & $\begin{array}{c}0.63 \pm 0.07 \\
(100)\end{array}$ \\
\hline 6 months & $\begin{array}{c}0.10 \pm 0.02 \\
(89.2 \pm 12.8)\end{array}$ & $\begin{array}{c}0.50 \pm 0.04 \\
(109.6 \pm 11.9)\end{array}$ & $\begin{array}{c}0.20 \pm 0.03^{\S \varsigma} \\
(155.7 \pm 39.8)\end{array}$ & $\begin{array}{c}0.58 \pm 0.08 \\
(142.0 \pm 22.2)\end{array}$ & $\begin{array}{c}0.12 \pm 0.03 \\
(84.7 \pm 11.4)\end{array}$ & $\begin{array}{c}0.51 \pm 0.10 \\
(97.6 \pm 10.9)\end{array}$ & $\begin{array}{c}0.21 \pm 0.04^{55} \\
(138.8 \pm 24.0)\end{array}$ & $\begin{array}{c}0.64 \pm 0.10 \\
(105.6 \pm 10.5)\end{array}$ \\
\hline 12 months & $\begin{array}{c}0.11 \pm 0.02 \\
(111.8 \pm 17.4)\end{array}$ & $\begin{array}{c}0.56 \pm 0.08 \\
(126.3 \pm 15.5)\end{array}$ & $\begin{array}{c}0.14 \pm 0.04 \\
(109.3 \pm 37.6)\end{array}$ & $\begin{array}{c}0.52 \pm 0.07 \\
(138.9 \pm 19.5)\end{array}$ & $\begin{array}{c}0.11 \pm 0.02 \\
(90.3 \pm 14.5)\end{array}$ & $\begin{array}{c}0.54 \pm 0.11 \\
(102.4 \pm 13.9)\end{array}$ & $\begin{array}{c}0.16 \pm 0.02 \\
(118.9 \pm 21.8)\end{array}$ & $\begin{array}{c}0.65 \pm 0.12 \\
(104.8 \pm 10.8)\end{array}$ \\
\hline 18 months & $\begin{array}{c}0.10 \pm 0.02 \\
(95.3 \pm 22.9)\end{array}$ & $\begin{array}{c}0.50 \pm 0.05 \\
(112.8 \pm 19.1)\end{array}$ & $\begin{array}{c}0.16 \pm 0.04 \\
(127.0 \pm 31.4)\end{array}$ & $\begin{array}{c}0.48 \pm 0.08 \\
(125.1 \pm 15.7)\end{array}$ & $\begin{array}{c}0.11 \pm 0.02 \\
(104.9 \pm 21.5)\end{array}$ & $\begin{array}{c}0.55 \pm 0.11 \\
(111.7 \pm 11.8)\end{array}$ & $\begin{array}{c}0.18 \pm 0.05 \\
(127.6 \pm 24.2)\end{array}$ & $\begin{array}{c}0.74 \pm 0.11 \\
(95.3 \pm 8.5)\end{array}$ \\
\hline 24 months & $\begin{array}{c}0.13 \pm 0.03 \\
(140.3 \pm 32.1)\end{array}$ & $\begin{array}{c}0.52 \pm 0.05 \\
(114.3 \pm 15.1)\end{array}$ & $\begin{array}{c}0.18 \pm 0.05 \\
(96.5 \pm 10.3)\end{array}$ & $\begin{array}{c}0.50 \pm 0.09 \\
(116.0 \pm 24.2)\end{array}$ & $\begin{array}{c}0.10 \pm 0.02 \\
(100.4 \pm 18.8)\end{array}$ & $\begin{array}{c}0.42 \pm 0.03 \\
(97.4 \pm 10.7)\end{array}$ & $\begin{array}{c}0.19 \pm 0.06 \\
(136.6 \pm 42.2)\end{array}$ & $\begin{array}{c}0.65 \pm 0.09 \\
(83.1 \pm 6.2)\end{array}$ \\
\hline
\end{tabular}

Time course changes in urinary $\mathrm{Ca} / \mathrm{Cr}$ and $\mathrm{P} / \mathrm{Cr}$ ratios are listed in Table 4.

The percent change of these parameters when the initial values are taken as $100 \%$, are also listed. Inter- and intra-group comparisons of these parameters were macie by non-paired and paired Student's t-test (two-tailed), respectively.

$\S \S ; p<0.01$ vs control 


\section{5）副作用の発現について}

$\mathrm{E}$ 群の1例 (82才) において $\mathrm{E}$ 群剤投与後6ヶ月後に機能性出血の発現をみた。 $1 \alpha$ 群, MHF 群に おいてはみるべき副作用は存在しなかった。

\section{考察}

老人性骨粗鬆症の治療法の開発は急務である。本症の病因は多岐にわたるので，その治療法は単 一の治療モードのみならず，多様な治療モードを開発しておく必要があると考えられる。骨粗鬆症 の発症に閉経が深く関与していることについては周知の事実であるにもかかわらず，我が国におい て，女性ホルモン製剤の骨粗鬆症に対する治療効果は本格的に追求されてこなかった。そこで今回 我々は，我が国で従来主として用いられてきた $1 \alpha-\mathrm{OH} \mathrm{D}_{3}$ の治療効果と，結合型エストロゲン製 剂及び性ホルモン・甲状腺ホルモン合剤の治療効果を比較してみることとした。

ここで問題となる点は，まずこれら薬剤の治療効果の判定法である。骨粗鬆症は骨量の減少を来 す症候群であると定義されている ${ }^{15)}$ がこの骨量の減少は，海綿骨部位でより顕著に，またより早期 にあらわれるとされる ${ }^{16)}$ 。しかも臨床的に問題となる骨折は海綿骨部位に多く発生するので，現在 では海綿骨部位の骨密度測定が一般的に治療モニターとして用いられている。しかしながら本研究 の如く，主として老人性骨粗鬆症を検討対象とする際には海綿骨部位の骨密度の測定は必ずしもよ い手段とはいえない。 ${ }^{153} \mathrm{Gd}$ を用いた Dual photon absorptiometry の場合，画像クオリティーが必 ずしも良好ではないため，骨密度が極端に減少した例にあっては， bone edge detection に多大の

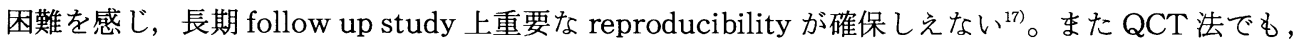
脊椎骨内の脂肪の介在により，骨塩量の under estimate を生じやすく，同様に reproducibility 確保しえないことが多い(18)。従って，長期 follow up study ではしばしば末梢皮質骨部位の測定が 有利になるとい5現象を経験する ${ }^{4199}$ 。更に今回対照薬となった $\alpha-\mathrm{OH} \mathrm{D}_{3}$ の治療効果は，従来末 梢皮質骨部位で検討されてきた ${ }^{1)}$ 。従って精度上もまた従来の検討との比較上も今回は SPA 法に より，橈骨皮質部位での効果検討を行った。

我々は従来より SPA 法での CV 值を $3 \%$ と報告してきた ${ }^{14)}$ この CV 值，即ち longterm reproducibility を最も顕著に規定する factor は bone width 值の reproducibility である。今回の

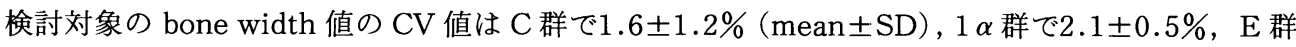

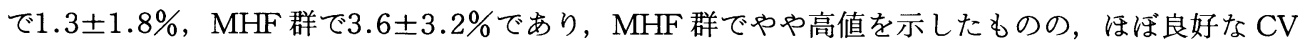
值が得られた。また今回の検討で $\alpha$ 群が 2 年目で約 $9 \%$ の骨密度の上昇を示した。この值は我々の 従来の報告值 ${ }^{1)}$ と全く一致し，この点でも SPA 法による経過追求が安定した方法であることがわ かる。

次に問題となるのは薬剤投与量の問題である。 $1 \alpha-\mathrm{OH} \mathrm{D}_{3}$ は過剩投与で高 $\mathrm{Ca}$ 血症を来すことが

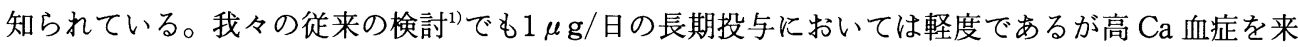
す例が散見されるため，今回は尿中 $\mathrm{Ca} / \mathrm{Cr}$ 比をモニターしつつ，1.0 0.5 $\mu \mathrm{g} /$ 日の可変用量とな した。結合型エストロゲンの投与量に関して，Lindsay ${ }^{20}$ はその最小有効量が $0.45 \mathrm{mg} /$ 日である としている。そこで今回はとりあえず，彼我の体重差を考慮して $0.3125 \mathrm{mg} /$ 日の投与量を選択した。 MHF 群投与量は本剂に含有される乾燥甲状腺末の投与量が問題となる。一般に甲状腺機能低下時 の乾燥甲状腺末の投与量は最低量が30 $50 \mathrm{mg} /$ 日といわれているので，それの半量即ち $15 \mathrm{mg} /$ 日と なるよう2錠/日の投与量を選択した。この投与量により甲状腺機能充進症を来した例は一例も存在 しなかった。 
このような投与量の薬剤に対し, 老人性骨粗鬆症の骨密度は, 増加した。しかし, その増加の程 度及びパターンは各薬剤で微妙に異なっていることが示された。即ち, 骨密度増加の程度は最高值 でみると， $1 \alpha$ 群 $9 \%, \mathrm{E}$ 群6\%及び MHF 群に12\%であり, MHF 群は $\mathrm{E}$ 群に比し約2倍の増加率で あった。また $\mathrm{E}$ 群においては, 一旦増加に傾いた骨密度が2年後には減少に転じた点も興味深い。 このような骨密度変化上の差異が, どのような機序によるものであるのかについては明らかではな いが, 今回の検討で興味深い現象が観察された。即ち, E 群における PTH の変動と, MHF 群に おける $\mathrm{A} 1$ - P值の変動がそれである。E群において最も顕著にみられた現象は血清 PTH 值が $0.28 \mathrm{ng} / \mathrm{ml}$ より，0.55ng/ $\mathrm{ml}$ へ約 2.5 倍に上昇した点である。Greenberg らによれば estradiol や progesterone は直接的に PTH 分泌を促進するといら ${ }^{21)}$ 。また Gallagher らは骨粗鬆症例に結合 型エストロゲンを投与すると, 血清 Ca 值の低下とともに, PTH の上昇をみたとい ${ }^{21}$ 。我々の結 果はこれら以前の観察事実をはるかに上回る PTH 分泌の充進をみたのである。Gallagher ${ }^{22}$ は 閉経直後の比較的若年（60才代）の婦人を用いての検討であるのに比し，今回の我々の検討では老 年女性（70才代）を用いてのものであったため, より, 二次性副甲状腺機能克進症が発現し易かっ たのかもしれない。E群における骨密度の増加維持が不可能であった理由は，この二次性副甲状腺 機能充進症と思われる, PTH 分泌充進が原因である可能性がある。

一方 MHF 群に扔いて何故骨密度が持続的に増加するかについてはその機序は不明である。本剤 は多様な性ホルモンと甲状腺ホルモンの合剂である。しかし, 一般に Native steroids を経口的に 投与せしめても，その血中への移行は極めて不良であるとされている。矢内原ら ${ }^{23}$ は本剤投与後, 血中の各ステロイド濃度がわずかに上昇したと報告しており, 全く本剂中のステロイドが吸収され ない訳ではなさそらである。しかし，もしこれら性ホルモンが作用機序の全てを説明しうるとすれ ば，MHF 投与により，例学ば $\mathrm{E}$ 群と同等な生物効果があると思われる。しかるに，MHF群で最 も顕著にあらわれた効果は一過性の $\mathrm{A} 1$ - P の上昇と, 持続性 $\mathrm{Ca}$ 低下及び一過性の P の低下であっ た。特に $\mathrm{A} 1-\mathrm{P}$ の上昇は一過性とはいえ顕著であり, この $\mathrm{A} 1-\mathrm{P}$ の上昇は甲状腺機能六進時にみ られる $\mathrm{A} 1-\mathrm{P}$ の上昇と同一機序, 即ち骨芽細胞機能の六進の結果である可能性もある。骨芽細胞 機能の亢進とそれに続く石灰化の促進により，Ca，Pとともに低下したのかもしれない。本剤が， はたして骨新生を促進したのか否かについては, 今後組織学的にも, また血中 BGP やコラーゲン 代謝の検討を行って確認する必要があると考えられた。

これら薬剤の 2 年間の投与中における副作用としては， $\mathrm{E}$ 群において1例の機能性出血をみたにと どまった。1 $\alpha$ 群で BUN, Crの上昇を認めたが，いずれも正常範囲内の変動であった。従って, これら各薬剤は安全に骨粗鬆症治療薬として使用しらるものと思われるが, その使用法, 使用量及 び作用機序につき更なる検討が必要に思われた。

結語

老人性骨粗鬆症の治療法を開発する目的で女性ホルモン剂及び性ホルモン・甲状腺ホルモン合剤 の骨密度に対する効果を $1 \alpha-\mathrm{OH} \mathrm{D}_{3}$ のそれと比較検討した。

対象は67例の老人性骨粗鬆症を有する高齢者女性である。対象を無治療群 28 例（C群）, $1 \alpha-$ $\mathrm{OH} \mathrm{D}_{3} 0.5 \sim 1.0 \mu \mathrm{g} /$ 日投与群 14 例（1 $\alpha$ 群），結合型エストロゲン $0.3125 \mathrm{mg} /$ 日投与群 12 例（E群） 及び性ホルモン・甲状腺ホルモン 2 錠/日投与群 13 例（MHF 群）に分割し，2年間の継続観察を行っ た。 
左橈骨遠位端 $1 / 3$ 部分を SPA 法で測定した骨密度変化率は投与前值を $100 \%$ とすると， 2 年後に

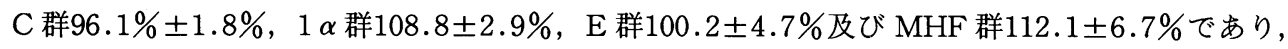
$1 \alpha$ 群と MHF 群は $(\mathrm{p}<0.01)$ に 群に比し骨密度が増加した。 $\mathrm{E}$ 群は投与 12 ケ及び18ヶ月でそ

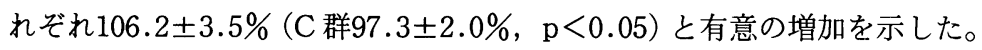

各群において血清 $\mathrm{Ca}, \mathrm{P}, \mathrm{A} 1-\mathrm{P}, \mathrm{BUN}, \mathrm{Cr}, \mathrm{PTH}$ 值及び尿 $\mathrm{Ca} / \mathrm{Cr}$, 尿 $\mathrm{P} / \mathrm{Cr}$ が検討された。

$\mathrm{E}$ 群において，投与後持続的に血清 $\mathrm{PTH}$ 值は上昇をつづけ，投与前值 $0.28 \pm 0.03 \mathrm{ng} / \mathrm{ml}$ より 6 ヶ 月 $0.40 \pm 0.06 \mathrm{ng} / \mathrm{ml}, 12$ ヶ月 $0.48 \pm 0.10 \mathrm{ng} / \mathrm{ml}, 18$ ヶ $0.53 \pm 0.12 \mathrm{ng} / \mathrm{ml}$ 及び 24 ヶ 月で $0.55 \pm$ $0.15 \mathrm{ng} / \mathrm{ml}$ へと約 2.5 倍の上昇をみた。これに対応して $\mathrm{E}$ 群の尿中 $\mathrm{Ca} / \mathrm{Cr}$ 比は前值 $0.14 \pm 0.02$ よ

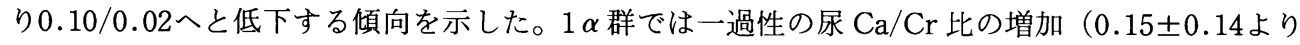

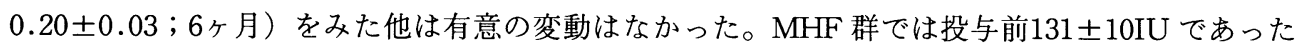
$\mathrm{A} 1-\mathrm{P}$ 活性が6ヶ月後及び12ヶ月後にそれぞれ151 $12 \mathrm{IU}$ 及び $158 \pm 13 \mathrm{IU}$ へと有意 $(\mathrm{p}<0.05,0.01)$ に上昇し，その後低下した。この群において血清 $\mathrm{Ca}$ 值は投与 18 ケ後及び 24 ヶ月後に投与前值 $9.6 \pm 0.1 \mathrm{mg} / \mathrm{dl}$ よりそれぞれ $9.1 \pm 0.2 \mathrm{mg} / \mathrm{dl}$ へと低下した。

以上の結果は今回検討した 3 種の薬剂が，それぞれ異なった作用機序で骨密度を増加せしめてい る可能性を示すものと考えられた。

文献

1) M. Shiraki, H. Orimo, H. Ito, I. Akiguchi, J. Nakao, R. Takahashi and S. Ishizuka: Long-term treatment of postmenopousal osteoporosis with active vitamin $\mathrm{D}_{3}, 1$ alpha-hydroxycholecalciferol $\left(1 \alpha-\mathrm{OHD}_{3}\right)$ and 1,24 dihydroxycholecalciferol $\left(1,24(\mathrm{OH})_{2}\right.$ $\mathrm{D}_{3}$ ). Endocrinol. Japon., 32: 305-315, 1985.

2) H. Orimo, M. Shiraki, Y. Hayashi and T. Nakamura: Reduced occurence of vertebral crush fractures in senile osteoporosis treated with $1 \alpha-\mathrm{OH}$-vitamin $\mathrm{D}_{3}$. Bone and Mineral, 3: 47-52, 1987.

3）白木正孝, 井藤英喜, 折茂 肇 : $1,25(\mathrm{OH})_{2} \mathrm{D}_{3}$ の老人性骨粗鬆症例の骨塩含量に対する効果一 主として用量反応関係について一. 日内分泌会誌，65：1253-1263，1989.

4) 藤田拓男, 井上哲郎, 折茂 肇, 高橋栄明, 森田陸司, 山室隆夫, 山本吉蔵, 吉川靖三: 骨粗根症に対する工 ルカトニンの効果プラセボを対照薬とした多施設二重盲検比較試験. 医学のあゆみ, 152: 261-282, 1990. 5) R. Lindsay, DM. Hart, JM. Aitken, EB. McDonald, J. Anderson and AC. Clarke: Long-term prevension of postmenopausal osteoporosis by oestrongen: evidence for on increased bone mass after delayed onset of oestrogen treatment. Lancet, 1: 1038-1041, 1976.

6) GF. Jensen, C. Christiansen and I. Transb $\phi 1$ : Treatment of postmenopausal osteoporosis: a controlled therapeutic trial comparing oestrongen/gestagen, 1,25-dihydroxy-vitamin $\mathrm{D}_{3}$ and calcium. Clin. Endocrinol. (Oxf.), 16: $515-524,1982$.

7) RR. Recker, PD. Saville and RP. Heaney: Effect of estrogens and calcium carbonate on bone loss in postmenopausal women. Ann. Intern. Med., 87: 649-655, 1977. 8) BR. Goldin, H. Adlercreutz, SL. Gobach, MN. Woods, JT. Dwyer, T. Colon, E. Bohn and SN. Gershoff: The relationship between estrogen levels and diets of Caucasian America and Oriental immigrant women. Am. J. Clin. Nutr., 44: 945-953, 1986.

9) 白木正孝, 井藤英喜, 折茂 肇：血中 $1,25(\mathrm{OH})_{2}$ 
Dの低值は骨折発生及び骨量减少の危険因子である。目骨代謝会誌，7:38-48, 1989.

10) BEC. Nordin, A. Robertson, RF. Seamark, A. Bridges, JC. Philcox, AG. Need, M. Horowitz, HA. Morris and S. Dean: The relation between calcium absorption, serum dehydroepiandrosterone and vertebal mineral density in postmenopausal women. J. Clin. Endocrinol. Metab., 60:651-657, $1985 . \quad 11)$ C. Slemenda, SL. Hui, C. Longcope and CC. Johnston: Sex steroids and bone mass. A study of changes about the time of menopause. J. Clin. Invest. , 80: 1261-1269, 1987. $12 ）$ 大西利夫, 広中隆志, 今中 俊爾, 土屋寛泰, 金 章湮, 福尾恵介, 森本茂人, 高 栄男, 多浦良彦, 熊原雄一: 老人性骨粗鬆 症に対するメサルモン-F の有用性について．ホルモンと臨床，35：859-861, 1987.

13）白木正孝, 折茂 肇 : 加齢と骨塩含量 第一報; 加齢に伴う骨塩含量の変化とその観察に抢け る photon absorption method の有用性. 日老医誌, 16:253-260, 1979.

14）白木正孝, 折茂 肇：Bone mineral analyzer, 骨代謝, 14:105-116, 1981. 15) F. Albright, PH. Smith and AM. Richardson: Postmenopausal osteoporosis. JAMA, 116: 2465-2474, 1941. 16) BL. Riggs, HW. Wahner, E. Seeman, KP. Offord, WL. Dann, RB. Mazess, KA. Johnson and LJ.Melton III: Changes in bone mineral density of the proximal femur and spine with aging. Defferences between the postmenopausal and senile osteoporosis syndromes. J. Clin. Invest., 70: 716-723, 1982 . 17) BJ. Riis and C. Christiansen: Measurement of spinal or peripheral bone mass to estimate early postmenopausal bone loss? Am. J. Med., 84: 646-651, $1988 . \quad$ 18) HW. Wahner: Bone mineral measurements. In Nuclear Medicine Annual 1986, LM. Freeman and HS. Weissmann (eds). Raven Press, New York, 1986 pp.214-217. 19) L. Nials, J. Pbdenphant, BJ. Riis, A. Gotfredson and C. Christiansen: Usefulness of regional bone measurements in patients with osteoporotic fractures of the spine and distal forearm. J. Nucl. Med., 28: 960-965, $1987 . \quad 20)$ R. Lindsay, DM. Hart and DM. Clark: The minimum effective dose of estrogen for prevension of postmenopausal bone loss. J. Am. Obset. Gynecol., 63: 759-763, $1984 . \quad 21$ ) C. Greenberg, SC. Kukreja, EN. Bowser, GK. Hargis, WJ. Henderson and GA. Williams: Parathyroid hormone secretion: Effect of estradiol and progesterone. Metabolism, 36: 151-154, $1987 . \quad 22)$ JC. Gallagher, BL. Riggs and HF. DeLuca: Effect of estrogen on calcium absorption and serum vitamin D metabolites in postmenopausal osteoporosis. J. Clin. Endocrinol. Metab., 51: 1359-1363, 1980. 23）矢内原巧, 植村和幸, 鈴木真由美, 中山徹也, 佐藤則子, 中山 秀夫：Metharmon-F 投与後の血中ホルモンの変動. ホルモンと臨床，35：469-474, 1987.

(受付日：'90.6.11)

（採択日：' 90. 8.20) 